\title{
Benford's Law Test Method in Tax Audit Planning
}

\author{
Darhasani and Fadlil Usman
}

\section{ABSTRACT}

\begin{abstract}
The purpose of this research is to test whether the Benford's Law test method can be used in tax audit planning. This research uses data on tax invoices of periodic VAT Tax Return registered in local tax office. The research was carried out by going through the identification and extraction stages of the first and second digits. The results show that Benford's Law can be used as an alternative method to indicate an improper periodic tax invoice. In addition, Benford's Law can also provide an assessment of which sectors and areas have indications of improper periodic tax invoice compared to other sectors and areas. Indications from this assessment can be used as a focus in planning tax invoice audit.
\end{abstract}

Keywords: Audit Planning, Benford's Law, Tax Invoice, Periodic VAT, Tax Bill.

\section{INTRODUCTION}

In order to increase tax revenue, Indonesian tax reform was carried out on the tax collection system from Official Assessment to Self Assessment, improvement of tax administration and law enforcement. Tax reform began in 1983 and currently tax revenues have become the backbone of state revenue.

In general, around $70 \%$ of state revenue posts are contributed by the taxation sector. Even in the 2017 state budget, the tax revenue mandate (Income Tax, Value Added Tax, and Land and Building Tax in the Forestry and Mining sector) which is the responsibility of the Directorate General of Taxes is targeted at $74.71 \%$ of total state revenue. In fact, over time, the realization of tax revenues continues to decline. In 2009 the realization of tax revenues reached $97.99 \%$ but decreased in the following years and in 2016 the realization of tax revenues reached the lowest decline with the realization of $81.6 \%$ of the target.

The self-assessment tax collection system basically gives confidence to the taxpayers themselves to report and pay taxes owed based on tax laws and regulations. This collection system risks giving rise to the potential for non-compliance to pay taxes, Leon Yudkin in Pohan $(2013 ; 4)$ says that no one likes to pay taxes and it has been a natural human instinct to always try to avoid paying taxes. Based on the 2016 DGT performance report, the level of compliance of formal taxpayers, which is one component of DGT's performance, is at $63.15 \%$, an increase from previous years but still far from the target of $72.5 \%$.

Taxpayer compliance is an important factor in the realization of tax revenue (Laili, 2013), with a high level of taxpayer compliance, it is expected that later it will be directly proportional to the level of tax revenue. The problem of taxpayer compliance can arise in terms of law enforcement, Hutagaol $(2007,1)$ states that the government must apply the

\author{
Submitted : December 05, 2021 \\ Published : December 29, 2021 \\ ISSN: $2507-1076$ \\ DOI: $10.24018 /$ ejbmr.2021.6.6.1195 \\ Darhasani \\ Polytechnic of State Finance STAN, \\ Indonesia. \\ (e-mail: darhasani91@gmail.com) \\ Fadlil Usman* \\ Polytechnic of State Finance STAN, \\ Indonesia. \\ (e-mail: fadli1.81@pknstan.ac.id) \\ *Corresponding Author
}

law fairly to everyone, if anyone does not pay taxes, whoever he is will be subject to sanctions according to the provisions.

Based on Law Number 6 of 1983 concerning General Provisions and Tax Procedures as Amended several times, the latest by Law Number 16 of 2009, law enforcement of testing on self-assessment of taxpayers can be carried out by examination which is then issued a sanction in the form of a tax bill if it is known that the taxpayer is still lacking in paying his taxes or not reporting in accordance with the provisions of tax regulations.

However, considering the current condition with the number of taxpayers as of 2016 reaching 32,769,215 people with only 5,184 tax auditors, it is difficult to enforce the law by conducting a fair examination. With the current level of Audit Coverage Ratio (ACR), according to tax expert Yustinus Prastowo in the Center for Indonesia Taxation Analysis (2017), it is still at the level of $0.34 \%$, still far from the ideal level of $3 \%-5 \%$.

After the tax amnesty period is over, the Directorate General of Taxes issues Circular Letter Number SE11/PJ/2017 concerning Plans, Strategies, and Measurement of Audit Performance in 2017 which contains the preparation of a list of audit priority targets, audit raw materials, management of the completion of the overpaid tax return Restitution audit, optimizing Tax Auditors, special and thematic examinations nationally and regionally as a followup in preparation for law enforcement. In the plan, there are several stages of determining the audit target, the audit coverage ratio (ACR) target and the audit completion plan. The focus of the audit is determined on a periodic basis, namely the focus of the national examination, the focus of the regional office examination, and the focus of the local tax office examination.

Local tax office " $X$ " as one of the tax service offices which has a total number of taxpayers reaching 130,211 Effective Taxpayers with the number of tax invoices reported based on 
the system reaching 351,491 invoices per 2016 with a value of 1.13 trillion has limited human resources with only 10 tax inspectors in conducting the inspection. The strategy that can be done to improve the quality and productivity of effective audits in order to achieve taxpayer compliance is inspection management that is more focused on specific areas and sectors. The selection of taxpayers to be audited starts from selecting the type of sector and then narrowing down to the classification of business fields and then taxpayers to certain areas that have high risk. One of the risk management techniques in tax audit planning that can be used to identify indications of unreasonableness is Benford's Law.

Benford's Law is a law that comes from the results of Frank Albert Benford's research where a collection of numbers will naturally follow a certain pattern, this pattern is known as Benford's Law. Durtschi $(2004,31)$ says that Benford's Law is an analysis of the distribution pattern of the occurrence of the frequency of numbers that is effective in detecting fraud. According to Nigrini $(2012,26)$, Benford's Law is also relevant for use in forensic accounting. According to the Organization for Economic Co-operation and Development $(2010,21)$ the recommended test to see the manipulation of tax invoices is Benford's Law.

This study aims to test whether the Benford's Law test method can be used as an alternative method in identifying reported tax invoice irregularities and can provide an assessment of which sectors and areas have indications of unfairness compared to other sectors. An indication of unfairness occurs when there is an anomaly in the value of the tax invoice reported based on the results of the Benford's Law test. This study uses VAT Period tax invoice data registered at one of the Indonesian local tax offices for the 2014-2017 period.

\section{THEORETICAL FRAMEWORK}

\section{A. Definition of Audit}

According to Arens et. al $(2014,24)$ : "Auditing is the accumulation and evaluation of evidence about information to determine and report on the degree of correspondence between the information and established criteria. Auditing should be done by a competent, independent person".

Meanwhile, according to the Committee on Basic Auditing Concepts of The American Accounting Association in Boynton et. al $(2002,5)$, audit is: "A systematic process of obtaining and objectively evaluating evidence regarding assertions of economic activities and events, with the aim of determining the degree of correspondence between these assertions and predetermined criteria and the delivery of results. results to interested parties.

According to Sukrisno Agus $(2012,4)$ audit is: "an examination carried out critically and systematically by an independent party on the financial statements that have been prepared by management along with accounting records and supporting evidence, with the aim of being able to provide an opinion regarding fairness of the financial statements."

From the three definitions of the experts above, we can simply conclude that auditing is the collection and evaluation of information to then be compared against predetermined criteria carried out by competent and independent people.

\section{B. Type of Audit}

There are three types of audits according to Arens et. al (2014,32-33), namely:

(a) Operational Audit is an audit related to the activities of obtaining and evaluating evidence regarding the efficiency and effectiveness of operational activities and operating methods carried out by an entity to achieve certain objectives.

(b) Audit of Financial Statements is an audit to determine whether the financial statements that have been prepared have been presented fairly according to certain specific criteria that have been recognized, in this case, namely generally accepted accounting principles such as IFRS.

(c) Compliance Audit is an audit related to determining whether an activity or operation of an entity has been specified in accordance with the procedures, rules and regulations that have been determined by a higher position entity or other authority that is used as a comparison criterion.

\section{Type of Auditor}

There are various professionals who have a duty to carry out audits. According to Boynton et. al $(2002,8)$ there are three types of auditors, namely: (1) independent auditors, (2) internal auditors and (3) government auditors. While Arens et. al $(2014,35)$ classify it more broadly into four types, namely: (1) Public Accountant Auditors, (2) Government Auditors, (3) Tax Auditors and (4) Internal Auditors.

\section{Audit Planning}

In general, the audit implementation stage is divided into three stages, namely planning, implementation, and reporting. Arens et. al $(2014,1)$ divides the audit process into four phases, namely: (1) planning and designing the audit, (2) conducting substantive and control tests, (3) performing analytical procedures and (4) completing the audit and issuing reports. Planning is the initial stage in the audit, there are at least three reasons why the auditor must plan carefully. First, it allows the auditor to obtain sufficient enough evidence. Second, it helps keep audit cost within reach, and third, avoids misunderstandings with the auditee.

\section{E. Tax Audit}

Referring to the theory of the type of audit (audit), the tax audit is included in the category of compliance audit, because the tax audit aims to determine whether the taxpayer has complied with the formal and material provisions stipulated by tax regulations.

The definition of examination based on Law no. 6 of 1983 concerning General Provisions and Tax Procedures as Amended by Law Number 16 of 2009 is a series of activities to collect and process data, information, and/or evidence carried out objectively and professionally based on an audit standard for test compliance with the fulfillment of tax obligations and/or for other purposes in the context of implementing the provisions of tax laws and regulations.

\section{F. Audit of Period VAT}

In examining the periodic VAT tax return, the Tax Auditor must pay attention to the following matters:

a. Implement audit techniques deemed necessary in accordance with the audit plan and audit program.

b. Perform testing to prove the formal and material truth of the Tax Invoice. 
c. In the event that the Tax Invoice is issued using the einvoce application, the examiner does not need to test the formal requirements of the Tax Invoice. Meanwhile, for Tax Invoices that are not issued through the e-invoice application, testing of the formal requirements of the Tax Invoice is carried out in accordance with Article 13 of the VAT Law and its implementing rules.

d. Based on the explanation of Article 13 paragraph (9) of the VAT Law, Tax Invoices or certain documents whose position is equivalent to a Tax Invoice meet material requirements if they contain actual or actual information regarding the delivery of Taxable Goods and/or delivery of Taxable Services, export of Taxable Goods. Tangible Tax, export of Intangible Taxable Goods, export of Taxable Services, import of Taxable Goods, or utilization of Taxable Services and utilization of Intangible Taxable Goods from outside the Customs Area within the Customs Area.

e. To test the material requirements of the Tax Invoice as referred to in letter (d) the Tax Auditor shall at least test:

1) the correctness of the type and amount of Taxable Goods and/or Taxable Services delivered.

2) conformity of the types of Taxable Goods and/or Taxable Services with the business activities of the Taxpayer.

3 ) the truth of the selling price or replacement value of Taxable Goods and/or Taxable Services.

4) the truth of the taxable employer of the seller and the buyer, as stated in the Tax Invoice and not only based on the confirmation answer.

f. The Tax Auditor conducts tests on the Input Tax to ensure that the Input Tax credited is in accordance with the formal and material requirements of the Tax Invoice.

g. With respect to delivery of Taxable Goods and/or delivery of Taxable Services, export of Taxable Goods and/or Taxable Services, and/or import of Taxable Goods and/or Taxable Services that obtain facilities, the Tax Auditor must conduct tests on the formal requirements and Tax Invoice material and fulfillment of subjective and objective requirements from the use of VAT facilities in accordance with applicable regulations.

h. on Tax Invoices that do not meet the formal and/or material requirements are followed up by:

1) for the seller's Taxable Employer:

a) VAT that has been collected and deposited cannot be subject to negative correction;

b) is subject to administrative sanctions in accordance with Article 14 paragraph (4) of the general provisions of taxation Law; and/or

c) if there is an indication that the seller's Taxable Employer issued a Tax Invoice not based on the actual transaction and there is an indication of a criminal act in the taxation sector, it will be followed up with a proposal for preliminary evidence examination; and

2) for the buyer's Taxable Employer, the Tax Invoice cannot be credited in accordance with Article 9 paragraph (8) of the VAT Law.

i. To test the existence of export activities of Taxable Goods by means of the Tax Auditor testing the correctness of containers and means of transportation through Container tracking or vessel tracking.

\section{G. Benford's Law Theory}

Benford's Law is a law derived from Frank Albert Benford's research which states that there is a natural phenomenon related to the frequency of occurrence of numbers in a quantitative data set. His observations show that naturally the frequency of occurrence of the number 1 is greater than the number 9 . The frequency of occurrence of numbers in the first digit (first digit) of the phenomenon follows the logarithmic relationship as follows:

$$
\mathrm{Fa}=\log [\boldsymbol{a}+\mathbf{1} / \boldsymbol{a}]
$$

where $\mathrm{a}$ is the number $1,2,3,4,5,6,7,8,9$ and $\mathrm{Fa}$ is the frequency of occurrence. According to Nigrini (2000) there are five main tests to determine whether a data set follows the Benford's Law pattern, namely:

\section{a) First-Digits Test (FD)}

This test calculates the frequency of occurrence of the first digit in a quantitative data set, starting from 1 to 9. Prob (D1 $=\mathrm{d} 1)=\log [\mathbf{1}+\mathbf{1} / \boldsymbol{d} \mathbf{1}] ; \mathrm{d} 1\{1,2,3,4,5,6,7,8,9\}$.

\section{b) Second-Digits Test (SD)}

This test calculates the frequency of occurrence of the second digit in a quantitative data set. The formula used is Prob (D2 $=\mathrm{d} 2)=1 \sum \mathbf{9}=\mathbf{1}[\mathbf{1}+\mathbf{1} / \boldsymbol{d} \mathbf{1} \boldsymbol{d} 2]$; $\mathrm{d} 2\{0,1,2,3,4,5,6,7,8,9\}$.

c) First-Two Digits Test (F2D)

Function to calculate the frequency of occurrence of the first two digits in a set of quantitative data. For numbers that have only one digit, a " 0 " will be added after it. The formula used in this test is Prob $(\mathrm{D} 1 \mathrm{D} 2=\mathrm{d} 1 \mathrm{~d} 2)=\log [\mathbf{1}+/ \boldsymbol{d} 2]$; d2 $\{10,11,12, \ldots 99\}$.

\section{d) First-Three Digits Test (F3D)}

This test calculates the frequency of occurrence of the first three digits in a quantitative data set.

e) Last-Two Digits Test (L2D)

This test calculates the frequency of occurrence of the last two digits in a set of quantitative data.

\section{Methodology AND DATA}

\section{A. Overview of Research Objects}

This research was conducted at local Tax Office. Local Tax Office is a vertical agency of the Directorate General of Taxes which is under and responsible to the Regional Office of the Directorate General of Taxes. Its working area covers four regencies containing 52 districts and 739 sub-district with an area of $6,599.47 \mathrm{~km}^{2}$.

Based on the Regulation of the Minister of Finance Number 206.2/PMK.01/2014 concerning the Organization and Work Procedure of the Vertical Agency, the Directorate General of Taxes, local tax office has the following duties:

1. determination and issuance of tax law products;

2. administration of tax documents and files, receipt and processing of tax returns, as well as receipt of other letters;

3. tax counseling;

4. tax services;

5. implementation of Taxpayer registration;

6. implementation of extensification;

7. administration of tax receivables and implementation of 
tax collection;

8. implementation of tax audits;

9.supervising the compliance of Taxpayers' tax obligations;

10. implementation of tax consultations;

11. correction of tax assessments;

12. Land and Building Tax reduction; and

13. implementation of office administration.

As of 2016 there were 150,455 taxpayers registered with the local tax office under study consisting of 9,113 corporate taxpayers, 4,702 institutions that have the obligation to collect taxes and 136,640 individual taxpayers.

\section{B. Source and Data Type}

The type of data used in this study is secondary data. The secondary source in this study is tax invoice of Periodic VAT tax return from local tax office database system in the form of tax ID number, Sector, KLU, Tax Imposition Basis, and the Value of VAT collected. In addition, the tax bill on the tax ID number concerned is also a source of data as comparison data against Benford's Law analysis.

\section{Research Model}

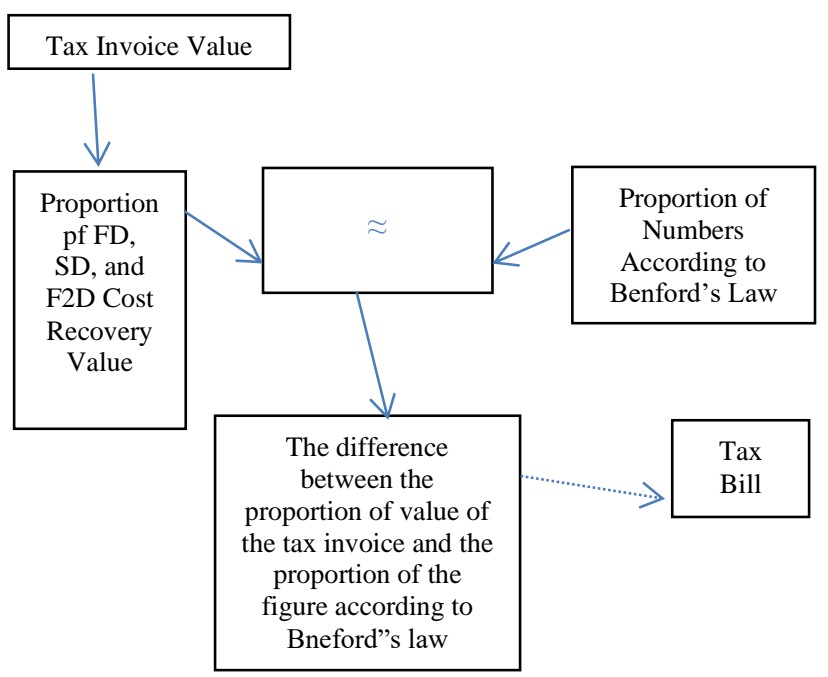

\section{Research Variables and Methods of Measurement}

This study uses two variables, the first is the fairness of the value of the Tax Invoice contained in the VAT Period tax return and the second is the Tax Bill. Data analysis was carried out with the following steps:

1. The process of collecting data from local tax office in the form of Data Set of Tax Invoices and Tax Bills which is the research variable.

2. Next, the data will be converted to Microsoft Excel to determine the first digit, second digit, and first two digits.

3. After separating the digits, an analysis is carried out using Benford's Law. In this study, only three types of tests used, namely First-Digits Test (FD), Second-Digits Test (SD), First-Two Digits Test (F2D).

\section{E. Conformity analysis with Benford's Law}

To test whether the Tax Invoice Set data has a pattern that is in accordance with Benford's Law, the analytical tools that can be used are Z-Statistics, chi square test and Mean Absolute Deviation (MAD). In this study, only Z-Statistic and MAD are used, while the chi square test is not used.
In Benford's Law, MAD is used to see the similarity of the pattern of the data studied with the pattern of Benford's Law. The MAD value can be calculated by using the equation:

$$
\mathrm{MAD}=\frac{\sum_{i=1}^{k}|A P-E P|}{k}
$$

where

EP: expected proportion;

AP: proportionactual;

$\mathrm{K}$ : number of data classes (e.g., 90 classes for the first two digits).

As a result, the critical value for the suitability of the data set with Benford's Law is categorized as in Table I. To test whether the actual proportion of a digit differs significantly from the expectations of Benford's Law, the Z-statistic test is used (Nigrini, 2012, 150). The Z-statistic formula is used to calculate the absolute difference (distance between actual and expected numbers), data set size, expected proportion.

TABLE I: CRITICAL VALUE AND STANDARD VALUE OF MAD

\begin{tabular}{|c|c|c|}
\hline Tes & Value Category & Conclusion \\
\hline \multirow{4}{*}{ FD } & 0,000 to 0,006 & Close confornity \\
\hline & 0,006 to 0,012 & Acceptable confornity \\
\hline & 0,012 to 0,015 & $\begin{array}{c}\text { Marginal acceptable } \\
\text { confornity }\end{array}$ \\
\hline & Over 0,015 & Nonconfornity \\
\hline \multirow{4}{*}{ SD } & 0,000 to 0,008 & Close confornity \\
\hline & 0,008 to 0,010 & Acceptable confornity \\
\hline & 0,010 to 0,012 & $\begin{array}{l}\text { Marginal acceptable } \\
\text { confornity }\end{array}$ \\
\hline & over 0,012 & Nonconfornity \\
\hline \multirow{4}{*}{ F2D } & 0,000 to 0,0012 & Close confornity \\
\hline & 0,0012 to 0,0018 & Acceptable confornity \\
\hline & 0,0018 to 0,0022 & $\begin{array}{l}\text { Marginal acceptable } \\
\text { confornity }\end{array}$ \\
\hline & Over 0,0022 & Nonconfornity \\
\hline
\end{tabular}

The calculation results are then compared with the table $\mathrm{z}$ values. The $z$ value used for comparison is $1.96(\alpha=0.05)$. The $\mathrm{z}$ value above the $\mathrm{z}$ table is considered abnormal and not in accordance with Benford's Law.

$$
\mathrm{Z}=\frac{|A P-E P|-\left(\frac{1}{2 N}\right)}{\frac{\sqrt{E P(1-E P)}}{N}}
$$

where

EP : Expected proportion;

AP : Actual Proportion;

$\mathrm{N}$ : Number of Records.

\section{F. Regression Analysis}

The regression model used is:

$$
\mathrm{Yi}=\frac{e^{u}}{1+e^{u}}
$$

where $\mathrm{Yi}$ is the probability of the group of audit findings and $\mathrm{u}$ is the regression:

$$
\mathrm{Y}=\mathrm{a}+\mathrm{b} 1 \mathrm{X} 1+\mathrm{b} 2 \mathrm{X} 2+\mathrm{b} 3 \mathrm{X} 3+\varepsilon
$$

In this analysis the dependent variable is the tax bill (Y), while the independent variable is the value of the proportion of the frequency pattern of the actual data value of the tax invoice with the proportion of the expected frequency pattern 
according to Benford's Law. These differences include differences in the first digit (first digit/FD), second digit (second digit/SD) and the first two digits (F2D). The magnitude of the difference is measured by the value of the Mean Absolute Deviation (MAD).

TABLE II: THE VALUE OF THE MEAN ABSOLUTE DEVIATION

\begin{tabular}{|c|c|c|c|}
\hline Var & Description & Type & Explanation \\
\hline XI & MAD FD & Independent & $\begin{array}{l}\text { The value of the difference between } \\
\text { the proportion of the actual number in } \\
\text { the first digit of the Cost Recovery } \\
\text { value and the number according to } \\
\text { Benford's Law }\end{array}$ \\
\hline $\mathrm{X} 2$ & MAD SD & Independent & $\begin{array}{l}\text { The value of the difference between } \\
\text { the proportion of the actual number in } \\
\text { the second digit of the Cost Recovery } \\
\text { value and the number according to } \\
\text { Benford's law }\end{array}$ \\
\hline X3 & MAD F2D & Independent & $\begin{array}{l}\text { The value of the difference between } \\
\text { the proportion of the actual number in } \\
\text { the first two digits of the Cost } \\
\text { Recovery value and the number } \\
\text { according to Benford's Law }\end{array}$ \\
\hline $\mathrm{Y}$ & $\begin{array}{l}\text { Audit } \\
\text { Finding }\end{array}$ & Dependent & Number of audit findings \\
\hline
\end{tabular}

Source: Processed.

\section{G. The Means Used for the Various Tests}

The program that will be used for statistical testing will be adapted to the conditions of the data that can use IBM SPSS 23, eviews 9, or STATA applications. In addition, Microsoft Office Excel data processing and ACL for Windows are also used.

\section{H. Expected results}

It is expected that high regression results between independent variables simultaneously on the dependent variable and independent variables individually on the dependent variable so that Benford's Law can be a reliable predictor in identifying the fairness of the value of tax invoices.

\section{Other Tests to Be Carried Out}

Other tests that will be carried out are the classical assumption test in the form of normality test, heteroscedasticity test, autocorrelation test, and multi collinearity test before performing regression analysis.

\section{RESUlt AND Discussion}

\section{A. Descriptive Statistical Analysis}

Before conducting data analysis, the first step is to ensure that the data to be analyzed is free from duplication and nuisance error data. From the results of data adjustments, there are several data that must be adjusted, namely (1) replacement invoice data and (2) tax invoices whose value is less than 100 . The results of the adjustment can be seen in Table III.

Furthermore, to find out whether the data set of tax invoice values meets the Benford's Law pattern, the following analysis is carried out:

a. The data set to be analyzed is a unified whole that describes a similar phenomenon.

b. The data set has no maximum or minimum limit (between certain numbers).

c. The data set is not a number that is formed intentionally or a number that is symbolized.

d. The data has a large size (the number of numbers is large).

e. Data belongs to an entity so that it can be distinguished from others.

f. Data has an average value (mean) greater than the median value.

$\mathrm{g}$. The data has a positive skewness value.

\section{B. Benford's Law Analysis}

The results of the analysis show that only 8 sectors out of 15 sectors are eligible to be tested for Benford's Law. The analysis of the first and second digits serves to provide an outline of whether the data set has anomalous data or deviations from the proportions of Benford's Law. The first two-digit analysis aims to further explore the discrepancy with the Benford's Law pattern.

The results of the analysis of the first and second digits are presented visually using a graph that illustrates the comparison between the actual proportion and the proportion according to Benford's Law, followed by an explanation of the analysis of the MAD test results for the digit group.

Then the explanation of the analysis of the results of the zstatistical test carried out on each class of numbers in a group of digits is described descriptively. Sectors that are eligible to be tested are as follows:

a. Wholesale and Retail Trade, Car and Motorcycle Repair and Maintenance Sector;

b. Processing Industry Sector;

c. Transportation and Warehousing Sector;

d. Agriculture, Forestry and Fisheries Sector;

e. Electricity, Gas, Steam/Hot Water and Cold Air Procurement Sector;

f. Construction Sector;

g. Financial Services and Insurance Sector;

h. Mining and Quarrying Sector.

TABLE III: INITIAL AND ADJUSTMENT OF VAT INVOICE DATA

\begin{tabular}{ccccccc}
\hline \multirow{2}{*}{ Period } & \multicolumn{3}{c}{ Preliminary data } & \multicolumn{4}{c}{ Data Adjustment } \\
\cline { 2 - 7 } & $\begin{array}{c}\text { Number of } \\
\text { Tax Invoice }\end{array}$ & $\begin{array}{c}\text { Number of } \\
\text { Sectors }\end{array}$ & $\begin{array}{c}\text { Number } \\
\text { of KLU }\end{array}$ & $\begin{array}{c}\text { Number of } \\
\text { Tax } \\
\text { Invoice }\end{array}$ & $\begin{array}{c}\text { Number of } \\
\text { Sectors }\end{array}$ & $\begin{array}{c}\text { Number } \\
\text { of KLU }\end{array}$ \\
\hline 2014 & 304.427 & 14 & 104 & 298.260 & 14 & 104 \\
2015 & 299.738 & 15 & 118 & 293.592 & 15 & 118 \\
2016 & 359.652 & 15 & 120 & 351.491 & 15 & 120 \\
2017 & 343.033 & 15 & 121 & 333.317 & 15 & 121 \\
\hline
\end{tabular}

Source: Processed. 


\section{Regression Analysis}

Regression calculations are performed using Eviews 9 and processing this data requires several stages which include the model approach, model selection, and election results. Based on the Chow test, Hausman test and Lagrange test, the most appropriate test to use is the Random effect model.

In addition, the classical assumption test was also carried out. The classical assumption test aims to make the Best Linear Unbiased Estimator (BLUE) regression model (Gujarati, 2004). This model uses a random effect model so that there are two classical assumption tests, namely the normality test and the multicollinearity test.

The test results show that there is multicollinearity between the independent variables FD and SD and the data is not normally distributed. After data transformation, this model is normally distributed.

Furthermore, hypothesis testing is carried out. In testing the hypothesis, the Coefficient of Determination Test (R2), Simultaneous Significance Test (F test) and Partial Significance Test (t test) were carried out.

The Coefficient of Determination Test (R2) was conducted to see whether the model has the ability to explain the dependent variable. Simultaneous Significance Test (F Test) was conducted to see whether the independent variables simultaneously had an effect on the dependent variable. Individual/Partial Significance Test (t test) was conducted to show the effect of each independent variable individually on the dependent variable.

\section{Discussion}

After analyzing using Benford's Law, it is known that Benford's Law analysis can be carried out on the tax invoice data set contained in KPP "X". Of the 15 sector classifications contained in the KPP " $\mathrm{X}$ " only 8 sectors that meet the requirements for analysis can be carried out. A summary of the results of the analysis is as follows:

From Table IV that in general, there are indications of impropriety in the data set of tax invoices in the 2014-2017 period. Overall, there are still many components of Benford's
Law analysis that show discrepancies. Of the eight sectors that were analyzed, only one sector was in conformity with Benford's Law in all periods from 2014 to 2017 for the first digit, second digit, and first two digit calculations, namely the Wholesale and Retail Trade, Repair and Maintenance of Cars and Motorcycles sector. Manufacturing industry sector; transportation and warehousing sector; agriculture, forestry, and fisheries sector; construction sector and Mining and quarrying sector have some compatibility in their FD, SD and F2D patterns. There are two sectors in which all periods and calculations do not match, namely the procurement of electricity, gas, steam/hot water sector and cold air as well as the financial services and insurance sector.

From the regression equation model, it can be concluded that together the independent variables have a significant effect on the dependent variable, but with the ability to explain which is still low, only $30.62 \%$. The MAD First Digit value is the first to be used as an independent variable, the results of the study show partially that the FD variable does not have a significant effect on tax bills. The second variable, namely the value of MAD SD also partially does not have a significant influence in determining the tax bill. The third variable is the MAD F2D value partially with a significance level above $95 \%$ indicating that MAD F2D has a significant effect on tax bills.

The inability of the FD, SD, and F2D variables to predict the existence of tax invoices irregularities is due to the absence of thorough research and examination of tax invoices, the tendency to focus attention on the dominant sector and due to differences in the auditor's ability.

Based on the audit plan, in accordance with existing policies, there are several stages of determining the audit target, the audit coverage ratio (ACR) target and the audit completion plan.

In completing the audit, there are components of the focus of the audit that must be carried out. The focus of the audit is determined on a periodic basis, namely the focus of the national audit, focus of the regional office audit, and the focus of the local office audit.

TABLE IV: RECAPITULATION OF BENFORD'S LAW ANALYSIS

\begin{tabular}{|c|c|c|c|c|c|c|c|c|c|c|c|c|}
\hline \multirow{2}{*}{ SECTOR } & \multicolumn{3}{|c|}{2014} & \multicolumn{3}{|c|}{2015} & \multicolumn{3}{|c|}{2016} & \multicolumn{3}{|c|}{2017} \\
\hline & FD & $\mathrm{SD}$ & F2D & FD & SD & F2D & FD & $\mathrm{SD}$ & F2D & FD & SD & F2D \\
\hline $\begin{array}{l}\text { Wholesale and } \\
\text { Retail Trade, Car } \\
\text { and Motorcycle } \\
\text { Repair and } \\
\text { Maintenance }\end{array}$ & $\mathrm{CC}$ & $\mathrm{CC}$ & $\mathrm{CC}$ & $\mathrm{CC}$ & $\mathrm{CC}$ & $\mathrm{CC}$ & $\mathrm{CC}$ & $\mathrm{CC}$ & $\mathrm{CC}$ & $\mathrm{CC}$ & $\mathrm{CC}$ & $\mathrm{AC}$ \\
\hline Processing Industry & MAC & MAC & $\mathrm{NC}$ & $\mathrm{NC}$ & $\mathrm{NC}$ & $\mathrm{NC}$ & $\mathrm{NC}$ & $\mathrm{AC}$ & $\mathrm{NC}$ & $\mathrm{NC}$ & MAC & $\mathrm{NC}$ \\
\hline $\begin{array}{l}\text { Transportation and } \\
\text { Warehousing }\end{array}$ & $\mathrm{NC}$ & $\mathrm{NC}$ & $\mathrm{NC}$ & $\mathrm{NC}$ & $\mathrm{NC}$ & $\mathrm{NC}$ & $\mathrm{NC}$ & $\mathrm{AC}$ & $\mathrm{NC}$ & $\mathrm{NC}$ & $\mathrm{NC}$ & $\mathrm{NC}$ \\
\hline $\begin{array}{l}\text { Agriculture, } \\
\text { Forestry and } \\
\text { Fisheries }\end{array}$ & $\mathrm{NC}$ & $\mathrm{NC}$ & $\mathrm{NC}$ & $\mathrm{NC}$ & $\mathrm{CC}$ & $\mathrm{NC}$ & $\mathrm{NC}$ & $\mathrm{CC}$ & $\mathrm{NC}$ & $\mathrm{NC}$ & $\mathrm{CC}$ & $\mathrm{NC}$ \\
\hline $\begin{array}{c}\text { Electricity, Gas, } \\
\text { Steam/Hot Water } \\
\text { and Cold Air } \\
\text { Procurement }\end{array}$ & $\mathrm{NC}$ & $\mathrm{NC}$ & $\mathrm{NC}$ & $\mathrm{NC}$ & $\mathrm{NC}$ & $\mathrm{NC}$ & $\mathrm{NC}$ & $\mathrm{NC}$ & $\mathrm{NC}$ & $\mathrm{NC}$ & $\mathrm{NC}$ & $\mathrm{NC}$ \\
\hline Construction & $\mathrm{NC}$ & $\mathrm{CC}$ & $\mathrm{NC}$ & MAC & $\mathrm{NC}$ & $\mathrm{NC}$ & $\mathrm{NC}$ & $\mathrm{CC}$ & $\mathrm{NC}$ & $\mathrm{NC}$ & $\mathrm{NC}$ & $\mathrm{NC}$ \\
\hline $\begin{array}{l}\text { Financial Services } \\
\text { and Insurance }\end{array}$ & $\mathrm{NC}$ & $\mathrm{NC}$ & $\mathrm{NC}$ & $\mathrm{NC}$ & $\mathrm{NC}$ & $\mathrm{NC}$ & $\mathrm{NC}$ & $\mathrm{NC}$ & $\mathrm{NC}$ & $\mathrm{NC}$ & $\mathrm{NC}$ & $\mathrm{NC}$ \\
\hline $\begin{array}{l}\text { Mining and } \\
\text { Quarrying }\end{array}$ & $\mathrm{NC}$ & $\mathrm{NC}$ & $\mathrm{NC}$ & $\mathrm{NC}$ & $\mathrm{NC}$ & $\mathrm{NC}$ & MAC & $\begin{array}{c}\text { MA } \\
\text { C }\end{array}$ & $\mathrm{NC}$ & $\mathrm{NC}$ & MAC & $\mathrm{NC}$ \\
\hline
\end{tabular}

$\mathrm{CC}=$ Close Conformity; $\mathrm{AC}=$ Acceptable Conformity; MAC=Marginally Acceptable Connformity; NC=Non Conformity . 
Previously audit policy was stated that the focus of the audit was on the dominant sector, then for the local tax office the three dominant sectors were (1) the wholesale and retail trade sector; Car and Motorcycle Repair and Maintenance; (2) Processing Industry; and (3) Agriculture, Forestry, and Fisheries and these positions have not changed in the last four years. If it is only focused on these three sectors, the audit can certainly not reach other sectors. Whereas based on the previous analysis, indications of irregularities exist in almost all existing sectors, in addition to the Wholesale and Retail Trade sectors; Repair and Maintenance of Cars and Motorcycles, which is one of the dominant sectors, turns out to have the lowest indications of irregularity compared to other sectors.

Benford's Law is carried out as an early indication stage in planning the audit and directing the focus of the audit. The non-compliance with Benford's Law found in these sectors can be followed up by focusing on further analysis on the component classes of numbers that show discrepancies. Benford's Law does not replace analytical procedures but serves as a supporting tool.

\section{CONCLUDING REMARKS}

Data sets of tax invoices can be analyzed using Benford's Law to determine which sectors have indications of improverness. Out of the 15 sectors, only eight sectors can be analyzed by Benford's Law. The seven sectors that were not analyzed have a small number of tax invoice data sets, which are less than 300 data which are considered less effective for analysis. Only the wholesale and retail trade, car and motorcycle repair and maintenance sector which is one of the dominant sectors has conformity with the Benford's Law pattern in the entire research and calculation period. While the rest show discrepancies that can be further explored to which class of numbers have indications of improperness. The results of the regression analysis show that simultaneously Benford's Law analysis can predict which reported tax invoices have indications of improperness.

Benford's Law can be used in tax audit planning to increase the focus of tax audit specifically in identifying improperness of reported tax invoices and providing an assessment of which sectors have indications of improperness compared to other sectors. It is hoped that the deterrent effect will hit all levels more, not just certain taxpayers. The justice aspect of law enforcement through audit can be applied to all taxpayers with the use of Benford's Law. It is hoped that the selection of tax invoices to be audited with the help of Benford's Law can reach tax Invoices from parties who have a high risk of improperness which in turn can affect the level of compliance of the Taxpayer as a whole.

\section{REFERENCES}

Azwar, S. (1995). Human Attitude: Theory and Its Measurement, Second Edition. Yogyakarta: Offset Student Library.

Alm, J. (2012). Measuring, explaining, and controlling tax evasion: lessons from theory, experiments, and field studies. International Tax and Public Finance, 19(1), 54-77. doi:10.1007/s10797-011-9171-2.

Azhar, M., Zakaria, M., H., \& Hamid, Z. (2016). Cash economy: Tax evasion amongst smes in Malaysia. Journal of Financial Crime, Vol.23, No.4, 974-986.
Basri, Yesi, M., \& Raja, A. (2014). The Influence of Justice, Expectation Norms, Sanctions, and Religiosity on Tax Intentions and Noncompliance. Accountability, vol. II no. 3, 162-176.

Benk, Serkan, et al. (2016). The impact of religiosity on tax compliance among Turkish self-employed taxpayers. Religions 2016, 7, 37; Doi:10.3390/Rel7040037.

Circular Letter of the Director General of Taxes Number SE-06/PJ/2016 concerning Audit Policy.

Darmayanti, T.W. (2004). Implementation of self assessment system according to taxpayer perception (Study on Salatiga corporate taxpayer). Journal of Economics and Business. vol. X No. 1, March 2004: 109-128.

Decree of the Minister of Finance Number 571/KMK.03/2003 dated December 29, 2003 concerning Amendment to Decree of the Minister of Finance Number 552/KMK.04/2000 concerning Limits for Small Entrepreneurs and Value Added Tax.

Directorate General of Taxes. (2017). Annual Report 2016. http://www.pajak.go.id/laporan-tahunan-2016-direktorat-jenderalpajak (Accessed: March 9, 2018).

Indonesia Government Regulation Number 46 of 2013 concerning Income Tax on Income from Business Received or Obtained by Taxpayers with Certain Gross Circulation.

Indonesia Income Tax Act. Law No.7/1983 concerning Income Tax as amended several times, most recently by Law No.36/2008.

Indonesia Law Number 6 of 1983 as last amended by Law Number 16 of 2009 concerning General Provisions and Tax Procedures.

Gunadi. (2005). Audit function on improvement of taxpayer compliance (Tax compliance). Indonesian Taxation Journal, Vol.4 no.5, 4-9.

Law of the Republic of Indonesia Number 20 of 2008 concerning Micro, Small and Medium Enterprises.

Mandagi, Sabijono \&Tirayoh. (2014). The Effect of tax audit on the compliance level of corporate taxpayers in fulfilling their tax obligations at KPP Pratama Manado. EMBA Journal, Vol.2, No.3, 1665-1674.

Sekaran, U. (2006). Research Methodology for Business: Book 1. Jakarta: Salemba Empat Publisher.

Sugiyono. 2010. Business Research Methods (Quantitative, Qualitative, and R\&D Approaches). Bandung: Alfabeta.

Sugiyono. (2011). Administrative Research Methods. Bandung: Alphabeta. Waluyo. (2007). Indonesian Taxation, Book 1, Edition 7. Jakarta: Salemba Empat. 